\title{
Cutaneous Squamous Cell Carcinoma of the Head and Neck PTX TNM Finding v8
}

National Cancer Institute

\section{Source}

National Cancer Institute. Cutaneous Squamous Cell Carcinoma of the Head and Neck pTX TNM Finding v8. NCI Thesaurus. Code C133204.

Cutaneous squamous cell carcinoma of the head and neck in which the primary tumor cannot be identified. (from AJCC 8th Ed.) 